\title{
Analyzing the Adoption of Recent IT Technologies in Undergraduate Engineering Project Course
}

\author{
Amol C. Adamuthe ${ }^{1}$, Sandeep U. Mane ${ }^{2}$ \\ ${ }^{1}$ Dept. of CS\&IT, Rajarambapu Institute of Technology, Rajaramnagar, MS, India \\ ${ }^{2}$ Dept. of CSE, Rajarambapu Institute of Technology, Rajaramnagar, MS, India \\ 1amol.admuthe@gmail.com \\ ${ }^{2}$ manesandip82@gmail.com
}

\begin{abstract}
Outcome-based professional education processes are a new standard for all stakeholders and knowledge economy. Majority of the time the IT services/consulting industry demands graduates who shall be billable from day one of joining the enterprise. According to the National Employability Report Engineers 2019, only 3\% of engineers possess new-age skills in areas such as AI, data analytics and mobile technologies. Academic project works shall be seen in the light of aforesaid observations and therefore suggests treating this as an opportunity to initiate undergraduates to more hands-on experiential learning considering the advancements in technology and market need. The objective of this paper is to identify the gap between the needs of the market/job trends and undergraduate CS/IT student projects areas. The second objective is to identify the factors affecting the project selection process.

Our empirical study in general spanning over seven Engineering Institutes in western Maharashtra. The statistical data is collected from a controlled group of 4000 students. The data consists of project topics completed by students in the last nine years (from the year 2011 to the year 2019). Two indicators are used to understand the IT market. First, Gartner strategic technologies present the worldwide trend of technologies. Second, student project areas are compared with job trends in India. The student's feedback on technology adoption theory presents the challenges in adoption of recent IT technologies in academic projects. $62 \%$ of students have reported unavailability of resources at the institute to encourage the adoption of the recent technologies. The student's perception about the adoption of recent technologies needs to change.
\end{abstract}

\section{Amol C. Adamuthe}

Dept. of CS\&IT, Rajarambapu Institute of

Technology, Rajaramnagar, MS, India

amol.admuthe@gmail.com

However, $85 \%$ of students agree that online resources can overcome the problem of availability of expert and guidance.
Keywords: CS/IT academic project selection, Gartner strategic technologies, CS/IT job/market trend.

\section{Introduction}

The current pandemic situation proved the significance of information and communication technology adoption in different sectors. According to IDC forecast cloud computing, mobile technologies, analytics and IoT are contributing significantly for enterprise growth. In the next few years robotics, artificial intelligence and AR/VR will reach $25 \%$ of ICT spending (IDC - Global ICT Spending: Forecast 2020 - 2023, 2020). Government of India has taken different initiatives for technology adoption in educational institutes. MHRD and AICTE have started different faculty development programs for improving the faculty competencies in different thrust areas such as artificial intelligence, data analytics, robotics, blockchain. AICTE promoted different new programs in recent technologies of artificial intelligence, machine learning, blockchain, data analytics, cybersecurity, Internet of things etc. IIT Mumbai, IIT Chennai, IIT Delhi and many more have taken initiative in this direction.

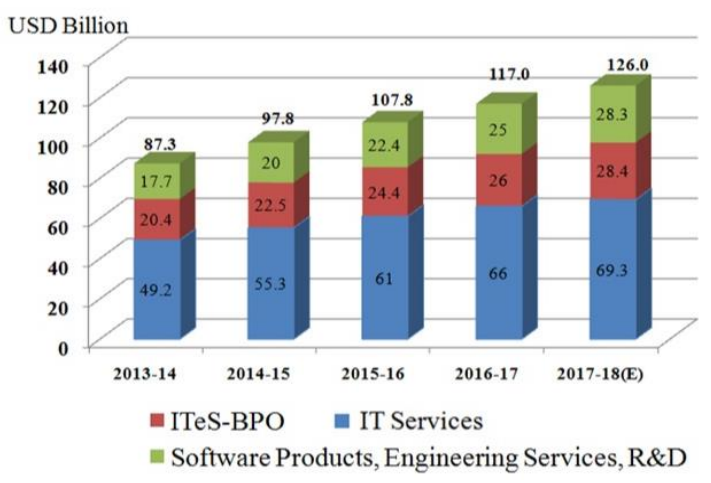

Fig.1 Top job roles in CS/IT in India (Ernst and Young, 2017)

Figure 1 shows the top job roles in the Indian information technology sector. From 2013-14 the jobs in IT services are increasing. The product development, engineering services and $R \& D$ increased rapidly. It creates the need for efficient manpower in recent IT technologies (Ernst \& Young, 2017). Aspiring Minds conducted and published an annual employability survey in 2019. According to the report, $80 \%$ of Indian engineering graduates are not fit for a job in the current knowledge economy. This report shows that the small changes in the education system will not address the 
actual problem. Engineering graduates are not industryready due to a lack of employability skills required in 2020. The employers across India looking for professional skills, problem-solving skills, lifelong learning skills and ethical responsibility from engineering graduates (Blom and Saeki, 2011). According to National Employability Report Engineers 2019, approximately 3\% of engineers possess new-age skills in areas such as AI, Machine Learning, Data Engineering and Mobile technologies. There is a wide gap between the IT industry and engineering institutes due to mismatch in industry expectations and academic practices. This gap is increasing significantly day by day due to lack of domain knowledge, inabilities of adopting recent technologies, old curriculum contents, poor assessment methodologies, etc. Academic project is an important part of the curriculum which expects the design and application of different knowledge and skills acquired by students. Project is an important course which demonstrates the knowledge of the students earned from various subjects they studied through the degree years. The quality of the project reflects the potential of students in various aspects of the development. The final year project is always an important topic of discussion during job interviews.

The main objective of the paper is to analyze the adoption of recent IT technologies in a capstone project course in undergraduate students of computer science or information technology. The two objectives of the paper are,

1. Identify the gap between the recent technologies, industry needs and undergraduate CS/IT student projects. Three is a need to check whether the project areas are in line with the market/industry needs.

2. Identify the factors affecting recent technology adoption in undergraduate projects.

The important contributions of the paper are as follows.

1. The paper analysed the recent technology growth using Gartner Strategic Technology list and market job trends.

2. Feedbacks from computer science or information technology undergraduate engineering students are taken. This feedback is used to analyse the use of recent technologies using technology adoption models.

The remaining paper is divided into various sections. Section 2 is about the proposed methodology, section 3 presents the analysis and finding. The conclusion is given in section 4 .

\section{Proposed Methodology}

\subsection{Data Collection}

The data is collected from seven engineering colleges from Western Maharashtra. The selected colleges are autonomous or university-affiliated. The project data is collected for the year 2011 to the year 2019. Approximately 4000 students are involved. Total of 945 project topics was analysed. Technology adoption is analysed through students' feedback. Questionnaires are prepared and feedback of 120 students is collected through online mode.

\subsection{Data Analysis Strategies}

\section{A. Analysis using Gartner Technologies}

Gartner defines "a strategic technology as one with the potential for significant impact on the enterprise in the next three years" (Cearley, 2014). According to David Cearley, vice president and distinguished analyst at Gartner"Strategic technologies affect, run, grow and transform the business initiatives of an organization".

The key issues behind strategic technology are (Cearley, 2014),

- Identify the technologies which have a high impact on enterprises in the coming three years.

- Identify the transformational or disruptive technologies

"A strategic technology may be an existing technology that has matured and/or become suitable for a wider range of uses," said Carl Claunch, vice president and distinguished analyst at Gartner. "It may also be an emerging technology that offers an opportunity for strategic business advantage for early adopters or with potential for significant market disruption in the next five years. Companies should evaluate these technologies and adjust based on their industry need, unique business needs, technology adoption model and other factors."

\section{B. Analysis using Market/Job Trend in India}

From more than two decades the information technology companies in India has shown a significant rise. Many global companies started their offices and research centres in India. According to various survey and research, it is observed that top job roles in CS/IT branch in India are Machine learning, Data scientist, mobile application development etc.

\section{Technology Adoption Models}

Identifying the acceptance of any new product or services of technology is an important concern for developers, designers, vendors and higher-level managers of adopting enterprise. In literature, different theories are available for technology adoption on country and enterprise. Each theory has some limitations. It provides some empirical evidence on the adoption of a specific product or technology in a given context. Intentions behind the use of IT technology and individual user response to it leads to actual adoption.

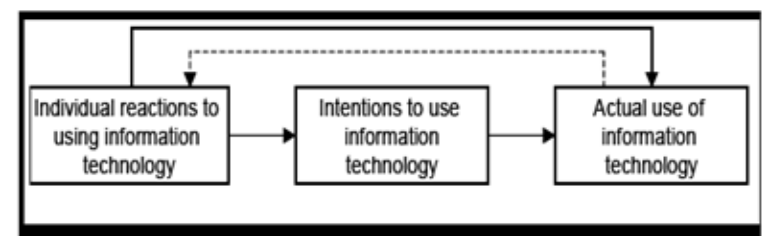

Fig. 2. Basic Concept Underlying User Acceptance Models (Venkatesh et al., 2003)

Figure 2 presents the basic concept behind the user acceptance models. The process of adopting new technology or innovation has been defined by the number of adoption models. Theory of Reasoned Action (TRA) and 
Theory of Planned Behaviour (TPB) is extensively investigated in ICT adoption. TRA and TPB give background for Technology Acceptance Model (TAM) and Enhanced TAM. Authors (Youngseek \& Crowston, 2011) listed how the constructs in TRA, TPB, TAM, Extended
Technology Acceptance Model (TAM2), Unified Theory of Acceptance and Use of Technology (UTAUT), Innovation Diffusion Theory (IDT), and Social Cognitive Theory (SCT) are related to each other (see Table 1).

Table 1. Comparison of Technology Adoption Theories

\begin{tabular}{|c|c|c|c|c|c|c|}
\hline UTAUT & TRA & TPB & TAM & TAM2 & IDT & SCT \\
\hline $\begin{array}{l}\text { Performance } \\
\text { expectancy }\end{array}$ & $\begin{array}{l}\text { Beliefs, } \\
\text { Attitude }\end{array}$ & $\begin{array}{l}\text { Beliefs, } \\
\text { Attitude }\end{array}$ & $\begin{array}{l}\text { Perceived } \\
\text { usefulness }\end{array}$ & $\begin{array}{l}\text { Perceived } \\
\text { usefulness }\end{array}$ & $\begin{array}{l}\text { Relative } \\
\text { advantage }\end{array}$ & $\begin{array}{l}\text { Outcome } \\
\text { expectations }\end{array}$ \\
\hline $\begin{array}{l}\text { Effort } \\
\text { expectancy }\end{array}$ & & $\begin{array}{l}\text { Perceived } \\
\text { behavioural control }\end{array}$ & $\begin{array}{l}\text { Perceived } \\
\text { ease of use }\end{array}$ & $\begin{array}{l}\text { Perceived ease } \\
\text { of use }\end{array}$ & Complexity & Self-efficacy \\
\hline Social influence & $\begin{array}{l}\text { Subjective } \\
\text { norm }\end{array}$ & Subjective norm & & $\begin{array}{l}\text { Subjective } \\
\text { norm, Image }\end{array}$ & & \\
\hline $\begin{array}{l}\text { Facilitating } \\
\text { conditions }\end{array}$ & & & & $\begin{array}{l}\text { Results } \\
\text { demonstrability }\end{array}$ & $\begin{array}{l}\text { Compatibility, } \\
\text { Observability, } \\
\text { Trailability }\end{array}$ & \\
\hline
\end{tabular}

\section{Analysis and Findings}

Project work at the undergraduate level, a compulsory part of any engineering programme getting practised in various Institutes/Universities in India. Academic projects are good indicators to analyse students learning experiences during the programme. This section presents the analysis of recent IT technology adoption on undergraduate project course in CS/IT engineering students.

\subsection{Analysis using Gartner strategic technologies from the} year 2011-2019

Gartner is a universal advisory and research organization. This provides information about the latest technologies used worldwide. Research provided by the Gartner has targeted senior managers of IT sectors. Gartner reviews and publishes the latest trends and current industry requirements that helps IT professionals/managers in decision making. In this work, strategic technologies from 2011 to 2019 are analysed (Market Trends: Worldwide, Top Five Disruptive Trends for CSPs, 2014-2019, 2014). Table 2 shows the classification of different technologies. The technologies are categorized into nine classes. This categorization is not complete but gives a general overview of technologies. As many of the technologies cover different technical and business aspect, they can be categorized into multiple classes.

Table 2. Categories of Technology by Gartner 2011-2019

\begin{tabular}{|l|l|}
\hline Sr. no. & Category \\
\hline 1 & Material Science and Electronics \\
\hline 2 & Rethink of Information Technology \\
\hline 3 & Communication \\
\hline 4 & Analytics \\
\hline
\end{tabular}

\begin{tabular}{|l|l|}
\hline 5 & Mobile related technologies \\
\hline 6 & Standardization in hardware, software, platforms, applications \\
\hline 7 & Artificial Intelligence \\
\hline 8 & New applications/business \\
\hline 9 & Web-related technologies \\
\hline 10 & The Internet of Everything \\
\hline 11 & Blockchain \\
\hline
\end{tabular}

Figure 3 shows the project topic analysis done based on the data collected from various engineering colleges in western Maharashtra. This graph represents the analysis of project topic domains from the year 2011 to 2019. For example, of the academic year, 2013 highest projects are from the Web Application domain. Cloud computing and sensor network comes in second and third rank respectively. Following are the top strategic technologies for the year 2012. Multimedia, mobile application, social user experience, Internet of Things, web-based application for marketing, nextgeneration analytics, Bigdata, In-Memory computing, Extreme low energy servers and Cloud computing. The job trends for the year 2012 are also observed. It is found that on top there was AI and at the bottom, there were IT security services. After the year 2017, the Internet of Things trend was leading many student's topics. In the year 2018, student projects selection is typically based on market job trends. The results show that from the year 2013 to 2016 students project domains were not in line with Gartner strategic technology trends and job trends in the Indian market. 


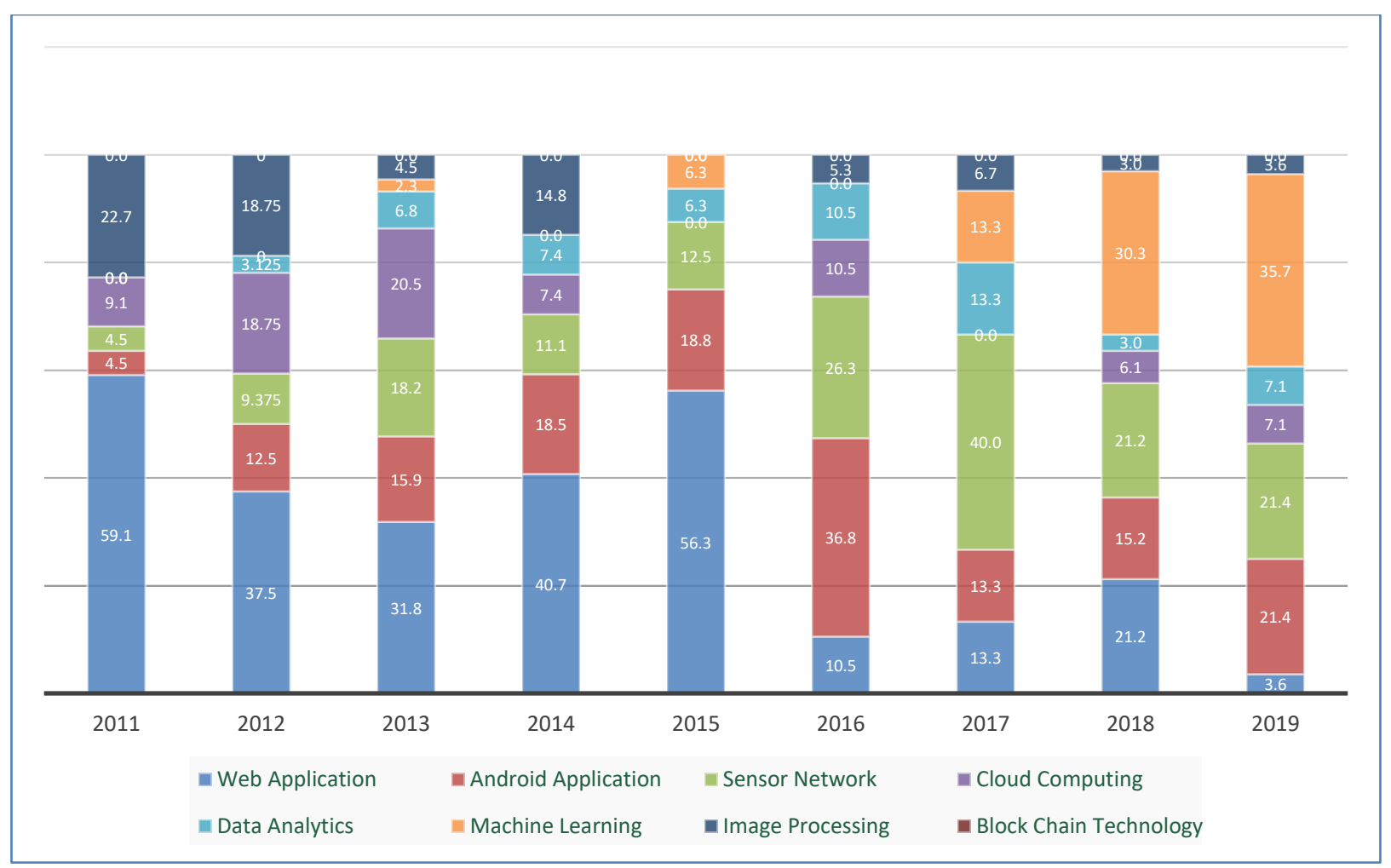

Fig. 3 Project Topics Analysis 2011-19

\subsection{Analysis using Market/Job trends in India}

The year 2005 to 2019 showed large growth in Indian IT industry. During this period maximum employment is created in this industry. It played a major role in changing the technology skillset requirement for employment in the market. Figure 4 shows the top job roles in CS/IT in India. The research is based on the responses collected from 114 engineering colleges across India during the first six months of 2018 (A study confirms that IIT and IIM graduates earn way more than their peers, 2018).

Machine learning
Data scientist
Security analyst
Business analyst
Web development
Product analyst
Software engineer
Software developer
Graphic software
Databuse admin
Network
Tech support
Quality analyst
Graduate engineer trainee
Business
Database manager
Program analyst

Fig. 4 Top job roles in CS/IT in India (Taken from (A study confirms that IIT and IIM graduates earn way more than their peers, 2018))

Figure 4 shows that increase in the number of employment in machine learning, data scientist, a security analyst and business analysts. The survey shows that machine learning is one of the most leading technology in the IT Industry.
Survey shows that demand for the latest technology practitioner students is increasing day by day (see Table 3). World's largest professional networking site LinkedIn says that top 5 and top 8-10 are fastest growing professional jobs in India are in the technology segment.

Table 3. Top Job Trends in India

\begin{tabular}{|l|l|}
\hline Top Job Trends & Employment Rate \\
\hline Machine Learning Engineer & $-------------------43 x$ \\
\hline Application Development Analyst & $-----------------32 x$ \\
\hline Back End Developer & $-----------23 x$ \\
\hline Full Stack Engineer & $-------18 x$ \\
\hline Data Scientist & $---14 x$ \\
\hline
\end{tabular}

World's largest professional networking site LinkedIn says that top 5 and top 8-10 are fastest growing professional jobs in India are in the technology segment. This analysis is done by a large number of users of LinkedIn in India. In another way, traditional jobs are getting replaced by recent technologies. Old promising titles are replacing with new titles. "In India, many businesses are shifting focus and resources to big data and digital products. Leaders across BFSI (banking, financial services \& insurance), manufacturing, media \& entertainment, professional services, retail \& consumer products, and technology software are looking at technology to drive scale, efficiency and growth. Machine-learning engineers and data scientists find themselves in massive demand," the report said (What 
are the top 10 emerging jobs in India, 2018). The new titles for era can be seen as follows.

- Machine Learning Engineer

- Application Development Analyst

- Back-end developers

- Full-stack Engineer

- Data Scientist

- Customer success manager

- Digital marketing specialist

- Big data developer

- Python developer

The above titles are playing the hottest job roles in the current IT Industry market. From that, the highest percentage is held by machine learning engineers and data scientists.
To conclude the student's behaviour on the project topic selection response is collected from 120 alumni. The question is,

"Who influenced you to choose academic project domain/topic?"

The responses are categorized into five types.

- Influencing Factor 1: Friends/Senior Suggestions

- Influencing Factor 2: Searched problems in society

- Influencing Factor 3: Guide/supervisor suggestion

- Influencing Factor 4: Easiness of development

- Influencing Factor 5: Self-analysis Technology/market survey/analysis

For the above question, responses are collected and formulated in the graph presented in Fig. 5.

3.3 Analysis using Students' Feedback

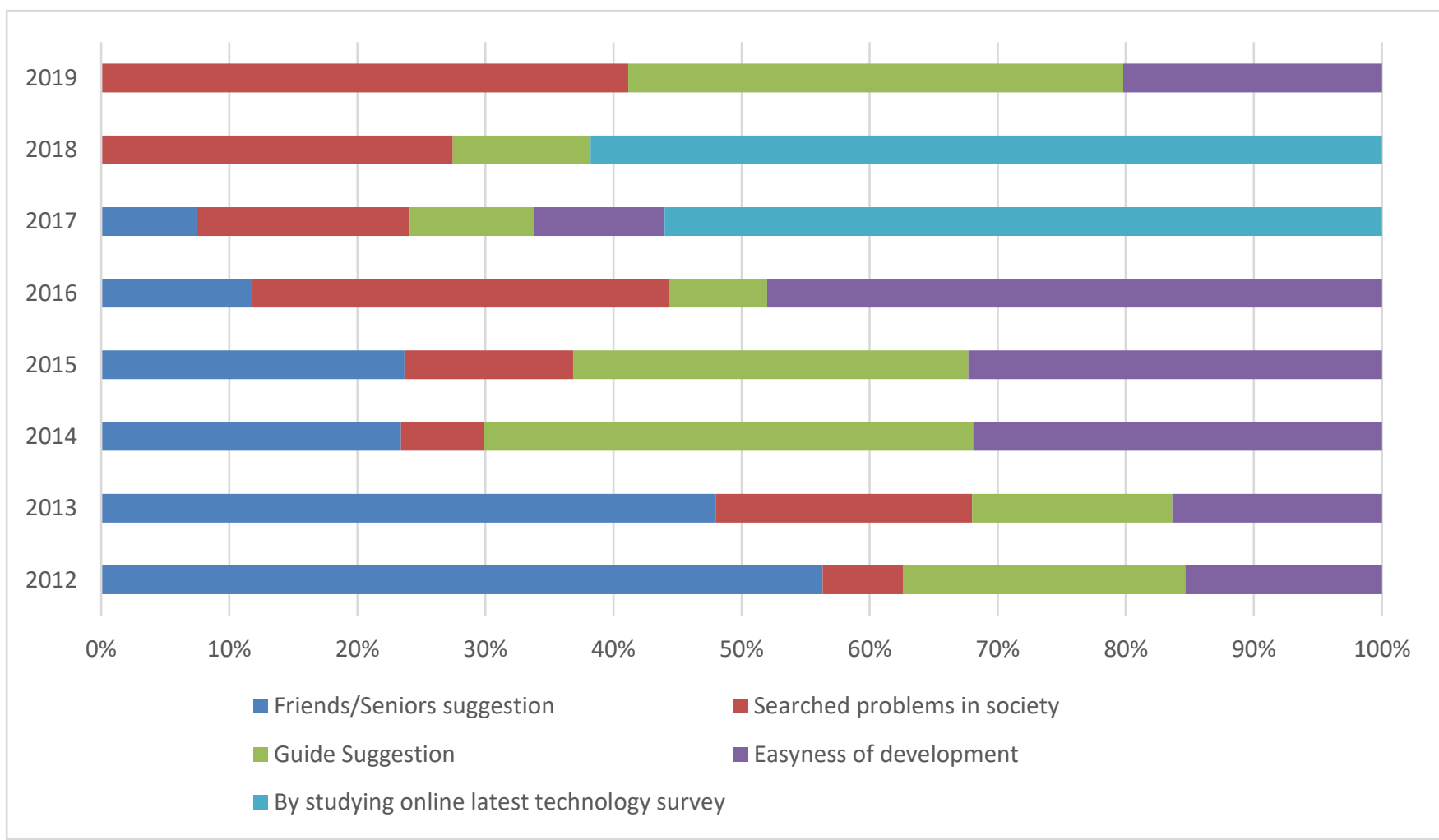

Fig. 5 Student feedback analysis

Results from fig. 5 show that in the year 2012 and year 2013 many students are influenced by their friend or senior student's suggestion regarding project topic selection. This influence is significantly reduced in the next years. The year 2018 and 2019 the influence is approximately zero or negligible. It leads to one negative indicator as weak interpersonal relations between students. There is scope to improve the interpersonal skills among students.

The survey is conducted to understand the factors behind the selection of the project topic. Curriculum and faculty competencies in recent technologies have a strong impact on student technology adoption. Guide or supervisor has an important role in exploring the technology adoption in the department. Faculty suggestion showed a significant impact on academic project selection in selected engineering colleges.

Results show that from the year 2012 to 2019 students involvement in searching for real-world problems for the academic project increased significantly. This leads to important indicators namely increase in students selflearning ability, motivation and interest in innovation. On the contrary, there is a large group of students who are interested in easy projects or repetitive projects.

The year 2017 and 2018 shows that students are aware of the different survey reports are available which helps to understand the recent technologies and adapt it for an undergraduate project. 
The questionaries' are prepared to analyze recent technology adoption by students considering technology adoption theories. Twelve questions are prepared considering nine points from the user perspective. Students feedback is presented in Table 4. From the analysis, it is observed that students have certain perceptions about new technology adoption. The majority of students are not sure about the usefulness of recent technologies for getting jobs or academic projects will lead to start-up or any new product or service. Other perceptions of students are difficult to use (32\%), costly $(47 \%)$, increase project completion time (46\%). Students have reported negatively about the resources available to adopt the recent technologies. $62 \%$ of students reported a lack of guidance to use new technologies at the institute. However, $85 \%$ of students agree that online resources can overcome the problem of availability of expert and guidance.

Table 4. Students' feedback on recent technology adoption

\begin{tabular}{|c|c|c|c|c|c|}
\hline \multirow{2}{*}{$\begin{array}{l}\text { Sr. } \\
\text { No. }\end{array}$} & \multirow[t]{2}{*}{ Questions } & \multicolumn{4}{|c|}{ Response (in \%) } \\
\hline & & $\begin{array}{l}\text { Strongly } \\
\text { Agree }\end{array}$ & Agree & Disagree & $\begin{array}{l}\text { Not } \\
\text { Sure }\end{array}$ \\
\hline \multirow[t]{4}{*}{1} & Perceived usefulness & & & & \\
\hline & Q1: Use of recent technologies are a must for job opportunities. & 10 & 30 & 40 & 20 \\
\hline & Q2: Academic projects will give start to a new idea and lead to a good start-up. & 1 & 20 & 30 & 49 \\
\hline & Q3: Academic projects will lead to new products or services. & 5 & 35 & 25 & 35 \\
\hline \multirow[t]{2}{*}{2} & Relative advantage & & & & \\
\hline & $\begin{array}{l}\text { Q4: Recent technologies are better than old technologies (cloud is better than cluster computing, IoT } \\
\text { is better than RFID, the mobile application is better than static web applications) }\end{array}$ & 20 & 50 & 12 & 18 \\
\hline \multirow[t]{2}{*}{3} & Ease of operation and saving of discomfort & & & & \\
\hline & Q5: Recent IT technologies are difficult to use. & 10 & 22 & 45 & 23 \\
\hline \multirow[t]{2}{*}{4} & Initial cost & & & & \\
\hline & Q6: Large/huge amount is required to use recent technologies for an academic project. & 7 & 40 & 29 & 24 \\
\hline \multirow[t]{2}{*}{5} & Saving of time & & & & \\
\hline & $\begin{array}{l}\text { Q7: New technologies (such as cloud, IoT, blockchain) will increase the project completion } \\
\text { duration. }\end{array}$ & 15 & 31 & 20 & 34 \\
\hline \multirow[t]{2}{*}{6} & Compatibility & & & & \\
\hline & Q8: New technologies have compatibility issues with existing systems and technologies & 20 & 43 & 19 & 18 \\
\hline \multirow[t]{2}{*}{7} & Complexity & & & & \\
\hline & Q9: Time required for purchase, install and use is more for new technologies. & 11 & 53 & 22 & 14 \\
\hline \multirow[t]{2}{*}{8} & Trialability & & & & \\
\hline & Q10: Trial versions of new technologies are available. & 16 & 36 & 32 & 16 \\
\hline \multirow[t]{3}{*}{9} & Facilitating conditions & & & & \\
\hline & Q11: Guidance for selection and use of recent technology is available in the institute. & 9 & 17 & 62 & 12 \\
\hline & $\begin{array}{l}\text { Q12: Guidance and support for use of recent technology is available through experts and online } \\
\text { mode }\end{array}$ & 25 & 60 & 7 & 8 \\
\hline
\end{tabular}

\section{Conclusions}

The information technology industry is changing very rapidly. With these changing technologies, job trends are also changing. Adoption of recent technologies is important to improve the employment of engineering students. Academic institutes and faculties must analyse the changing trend and scenario to create awareness among students of this regard. Analysing selection of technologies by final year students for projects is a good way for this analysis. The primary goal of this research paper is to identify the mismatch in technologies selected by undergraduate engineering students in academic projects and the actual job trends in the market. These findings are beneficial to students for selection of appropriate technology for the project.

In this research paper, we have analysed the project selection procedure of engineering students. Final year project is a collaboration of knowledge of all the subject a student learns in his/her educational years. We have analysed how the IT Industry change using Gartner technology strategies and job trends. Results show that there is a gap between student's project topics and the selection process with comparison to changing technology trend and industry expectations. Interactions with industry experts, alumni and reading technology survey reports is essential to improve the project topic domain selection. The analysis shows an increase in the number of employment and investment happening in recent IT technology such as artificial intelligence, machine learning, data science, cloud technologies etc. The adoption of these technologies in undergraduate projects is not satisfactory and slow. Approximately $62 \%$ of students have reported unavailability of resources at the institute to encourage the adoption of the recent technologies. However, $85 \%$ of students agree that online resources can overcome the problem of availability of expert and guidance. Institutes 
need to create awareness among students to change their perception and resistance to adopt recent technologies.

\section{References}

A study confirms that IIT and IIM graduates earn way more than their peers (2018). https://scroll.in/article/887051/astudy-confirms-that-iit-and-iim-graduates-earn-way-morethan-their-peers. last accessed in September 2020.

Bharadwaj, S. S., \& Lal, P. (2012, December). Exploring the impact of Cloud Computing adoption on organizational flexibility: A client perspective. In 2012 International Conference on Cloud Computing Technologies, Applications and Management (ICCCTAM) (pp. 121-131). IEEE.

Blom, A., \& Saeki, H. (2011). Employability and skill set of newly graduated engineers in India. The World Bank.

Briz-Ponce, L., Pereira, A., Carvalho, L., Juanes-Méndez, J. A., \& García-Peñalvo, F. J. (2017). Learning with mobile technologies-Students' behavior. Computers in Human Behavior, 72, 612-620.

Cearley, D. W. (2014). The top 10 strategic technology trends for 2014. Gartner Inc.

Future of jobs in India: http://www.ey.com/Publication/vwLUAssets/ey-future-ofjobs-in-india/\%24FILE/ey-future-of-jobs-in-india.pdf last accessed in October 2019

https://www.gartner.com/en/documents/2674717/markettrends-worldwide-top-five-disruptive-trends-for-c last accessed in September 2020.

https://www.gartner.com/en/newsroom last accessed in September 2020.

IDC - Global ICT Spending: Forecast 2020 - 2023 (2020). https://www.idc.com/promo/global-ict-spending/forecast last accessed in September 2020.

Kim, Y., \& Crowston, K. (2011). Technology adoption and use theory review for studying scientists' continued use of cyber-infrastructure. Proceedings of the American Society for Information Science and Technology, 48(1), 1-10.

Low, C., Chen, Y., \& Wu, M. (2011). Understanding the determinants of cloud computing adoption. Industrial management \& data systems, 111(7), 1006-1023.

Market Trends: Worldwide, Top Five Disruptive Trends for CSPs, 2014-2019 (2014).
Venkatesh, V., Morris, M. G., Davis, G. B., \& Davis, F. D. (2003). User acceptance of information technology: Toward a unified view. MIS Quarterly, 27(3), 425-478.

What are top 10 emerging jobs in India? (2018). https://www.dnaindia.com/business/report-what-are-top10-emerging-jobs-in-india-2660083 last accessed in September 2020. 